YuLIIA DZHEPA

Judge of Economic Court of Sumy Region, Ukraine,

Ph.D in Law,

Associate Professor of the Chair of Justice at

JOURNAL OF MODERN

SCIENCE TOM 3/42/2019,

Sumy National Agrarian University

dzhepa.j@ukr.net

ORCID: 0000-0002-0937-6982

OKSANA SOPIANENKO

Judge of Economic Court of Sumy Region, Ukraine

as77tra@gmail.com

\title{
Ensuring the Right to Peaceful Enjoyment OF Possessions In THE BANKRUPTCY Procedures of aN INDIVIDUAL IN UKRAINE
}

\begin{abstract}
The article is devoted to the review of bankruptcy procedures of an individual in Ukraine. In particular, attention is focused on guaranteeing the right to peaceful enjoyment of the individual's possessions.

KEYWORDS: bankruptcy, individual, insolvency, consumer bankruptcy, debt restructuring, scheme of composition, debt repayment procedure

\section{TEXT OF THE ARTICLE:}

The goal of the article is to study the peculiarities of bankruptcy procedures of an individual in Ukraine, the ratio of Ukrainian legislation innovations in this field and the right to peaceful enjoyment of possessions by a person guaranteed by article 1 of Protocol 1 to the Convention for the Protection of Human Rights and Fundamental Freedoms, which lies in the fact that no one may be deprived of their possessions except in the interests of society and under the conditions provided for by the law and the general principles of international law.
\end{abstract}


The legislation of countries in the field of bankruptcy of individuals differs both in history and approaches due to the influence of the following factors: historical experience, ideology, cultural characteristics, specific situation (for example, the financial crisis), which should be taken into consideration.

The following terms, similar to the bankruptcy procedures of an individual in Ukraine are used in the practice: "insolvency/bankruptcy of individuals/ citizens", "consumer/ individual/ personal bankruptcy/ insolvency".

In particular, if the US rules on consumer bankruptcy have been in force since the end of the 19th century, in Europe, the first relevant Law was adopted in Denmark in 1984, in Ukraine - in 2018 due to lending growth, including consumer and mortgage lending, that certainly indicates the relevance of the chosen topic in the Ukrainian legal science and practice.

In October 2018, the Verkhovna Rada of Ukraine adopted the Code of Bankruptcy Procedures of Ukraine, which introduced the procedure for bankruptcy of an individual that was revolutionary for Ukraine (it should be noted that the text of the Code has been neither signed by the President of Ukraine nor promulgated yet). [1]

Prior to the adoption of the above Code, the legislation on insolvency in Ukraine has provided only for procedures to restore the solvency (bankruptcy) of legal entities and individual entrepreneurs.

The prerequisite for the emergence of such an institution as consumer bankruptcy in the legislation of Ukraine is the need to support individuals who find themselves in a difficult financial situation and need assistance from the State. In a market economy, there are situations when a person is in financial straits not through her or his fault. Temporary financial difficulties for every citizen can occur due to job loss, divorce and the need to provide financial assistance to children, the loss of relatives or breadwinners and, finally, health. As a result, a person loses the opportunity to continue his or her ordinary professional activities. In addition, the cyclical development of the market economy involves both a rise and a fall in production which sometimes directly affects personal and family budgets.

In Ukraine, the citizens, who have received consumer loans for the purchase of real estate (residential property) in most cases in foreign currency, and currently are not able to settle accounts with banking institutions on granted 
loans and accrued penalties, find themselves in this situation. The Law of Ukraine "On Moratorium on Recovery of Property of Ukrainian Citizens Provided as Collateral for Foreign Currency Loans" adopted in June 2014 [2] has not addressed the problem of borrowers' debt relief.

Analyzing the provisions of the Code of Bankruptcy Procedures of Ukraine [1], it is seen that the initiation of bankruptcy proceedings of an individual is possible under the following conditions.

Firstly, a petition for bankruptcy shall be filed only by the debtor in cases where the overdue debt is more than 30 minimum wages (as of today, it amounts to $125,190 \mathrm{UAH}(4,150 \mathrm{EUR}))$, or the debtor has ceased to repay loans or make other scheduled payments of more than $50 \%$ of the monthly payments, or there are other circumstances confirming the inability to perform pecuniary obligations or make ordinary current payments.

Secondly, a moratorium for a period of 120 days, which provides for the suspension of the fulfillment of pecuniary obligations, the suspension of execution under executive documents, the suspension of the accrual of penalties, etc., is introduced from the moment of commencement of the proceedings.

The Code provides for the possibility of applying several procedures to debtors.

Debt restructuring (similar to the procedure of reorganization of debtors - legal entities) is introduced in order to overcome the crisis through payment by installments, debt release, change in timing of payments and carried out exclusively in accordance with the plan, which takes into account the income of the debtor, his/her property status, and in which the amounts to be sent monthly to repay the debt and the amounts to remain with the debtor are determined.

A scheme of composition is a settlement of debts on the basis of reciprocal concessions between debtor and creditors.

The procedure of debt repayment (similar to the liquidation procedure for legal entities) is introduced when it is impossible to repay the debts of creditors or there are no other ways except for the sale of the debtor's property. In this case, the property is included in the liquidation estate and sold for the purpose of satisfaction of all the creditor's claims. 
The main question, which, in our opinion, would arise in the practical application of the innovations of the Code of Bankruptcy Procedures of Ukraine, is how to protect the property right of the debtor and his/her family members'right to property (residential property).

Thus, the plan for restructuring the debtor's debts (as the first stage of restoring solvency) may contain the provision on sale of the debtor's property, including the property to be collateralized. Therefore, the possibility declared by the legislator to reduce (or even to be released) the overdue debt under the credit for acquisition of residential property may result in the deprivation of this residential property.

Moreover, the timing of the implementation of the debtor's debt restructuring plan defined in the Code, which under normal conditions will not exceed five years, and in the case of repayment of debts under credit granted to the debtor for purchase of residential property, the period of implementing the debtor's debt restructuring plan shall not exceed ten years, gives rise to concern. And this is despite the fact that, according to its logic, the introduction of the bankruptcy procedure of an individual should contribute to the early release from debts by reciprocal concessions between debtor and creditors.

From the moment of declaring the debtor - an individual bankrupt, all the property of the debtor, which is owned and will be received by him/her until the completion of the debt repayment procedure, is included in the liquidation estate. An exception is housing, which is the only place of residence of the debtor's family (an apartment with a total area of not more than 60 square meters or a living area of not more than 13.65 square meters for each member of the debtor's family, a residential unit with a total area of not more than 120 square meters) and is not collateralized, as well as other property of the debtor, which in accordance with legislative acts may not be recovered. From this thesis it can be concluded that the residential property to be collateralized is not included in the liquidation estate and is subject to further sale.

The debtor's property in accordance with the Code will be sold at an auction via the electronic trading system. The most problematic situation in practice may be the one, when, in the case of non-sale of the debtor's property to be collateralized at the second re-auction, the creditor (and as usual it is 
the bank) has the right to appeal to the insolvency official with an application for sale of unsold property at the initial price of the relevant auction.

Unlike Ukraine, Western European countries have a well-developed social security system, which to some extent smoothes down the acuteness of the problem of over-indebtedness.

The European legislation violates moral issues when accessing a settlement procedure which requires a mandatory payment plan for debt repayment and offers debt counseling. The European legislation indicates that debt growth is rather a social than market problem [3].

The EC Council Regulation No. 1346/2000 dated 29th May 2000 on the procedures for the settlement of insolvency that applies to all legal entities and individuals, and establishes a system in which the judicial decision of one member country is recognized by other states, has been adopted with the aim of harmonization of the European legislation in this field.

The unification of the existing approaches in the bankruptcy procedure has been carried out by INSOL, the European organization of professionals who specialize in insolvency, bankruptcy and business reconstruction and recovery [4]. INSOL emphasizes the importance of instruments which go beyond the purely bankruptcy procedure and are rather a social infrastructure, and which should apply both to litigation (debt counseling and restructuring) and after the completion of the bankruptcy procedure (consulting and training on planning and managing the consumer budget).

The practice of the European Court of Human Rights in bankruptcy proceedings with respect to Ukraine, given the absence of bankruptcy proceedings for individuals until 2018, even in cases of bankruptcy of legal entities on the applications of their creditors - individuals is characterized by the focus on protection of the right to peaceful enjoyment of the possessions by a person guaranteed by article 1 of Protocol 1 to the Convention for the Protection of Human Rights and Fundamental Freedoms - the protection of property rights. In particular, in the case "Fuklev v. Ukraine" (application No. 71186/01), the European Court of Human Rights states that "the state, in particular, has an obligation to ensure that the procedure stipulated in the legislation on the implementation of decisions that have entered into force and bankruptcy proceedings shall be controlled" [5]. The focus of bankruptcy procedure on 
compliance with the provisions of article 1 of Protocol No. 1 is also indicated in the decision in the case "Semenov v. Ukraine" (application No. 25463/03) [6].

In our opinion, the introduction of the institution of bankruptcy of individuals in Ukraine without considering the best practice regarding its social orientation is projected to lead to a significant increase in the number of appeals to the European Court, however, in our opinion, the focus of its practice on strict observance of the rights of persons to peaceful enjoyment of their possessions, the state's observance of the balance between the public interest and the right of a person to protection of his or her property, will remain a priority.

The global experience in legal regulation of bankruptcy of individuals, the focus of the practice of the European Court of Human Rights on protecting the right of an individual to peaceful enjoyment of his/her possessions, the developments of scientists in the interpretation and improvement of the Code of Bankruptcy Procedures of Ukraine [1] should, according to the authors, be taken into account in the practical implementation of the relevant procedure by the economic courts of Ukraine.

\section{References}

Code of Bankruptcy Procedures of Ukraine dated October 18, 2018 (text of the bill for the second reading dated October 16, 2018)

Decision of the European Court of Human Rights dated June 07, 2005 "Case "Fuklev v. Ukraine” (application No. 71186/01) // https://zakon.rada.gov.ua/laws/ show/974_022

Decision of the European Court of Human Rights dated December 13, 2005 in the case "Semenov v. Ukraine" (application No. 25463/03) // http://khpg.org/index. php?id=1179316868

http://w1.c1.rada.gov.ua/pls/zweb2/webproc4_1?pf3511=63518

Law of Ukraine "On Moratorium on Recovery of Property of Ukrainian Citizens Provided as Collateral for Foreign Currency Loans” adopted in June 2014 // https:// zakon.rada.gov.ua/laws/show/1304-18

J. Niemi-Kiesiläinen. Consumer Bankruptcy In Comparison: Do We Cure A Market Failure Or A Social Problem?// https://www.schuldenberatung.at/downloads/infodatenbank/information-englisch/bankruptcy_comparison_sf.pdf

Internation al Association of Restructuring, Insolvency and Bankruptcy Professionals - INSOL International // https://www.insol.org/ 